\title{
Minimum Effective Dose of Chlorantraniliprole and Chromafenozide to Control Oil Palm Bunch Moth Tirathaba mundella Walker
}

\author{
CHONG MING SU ${ }^{1}$, PATRICIA JIE HUNG KING*1,2, YEE MIN KWAN ${ }^{1}$, ZAKRY FITRI \\ AB AZIZ ${ }^{1,2} \&$ KIAN HUAT ONG ${ }^{1}$
}

\author{
${ }^{1}$ Faculty of Agricultural Science and Forestry, Universiti Putra Malaysia Bintulu Sarawak Campus, \\ Bintulu, Sarawak, Malaysia; ${ }^{2}$ Institut Ekosains Borneo, Universiti Putra Malaysia Bintulu Sarawak \\ Campus, Nyabau Road, 97008 Bintulu, Sarawak, Malaysia \\ *Corresponding author: patricia@upm.edu.my \\ Received: 23 March 2021 \\ Accepted: 19 May 2021 \\ Published: 30 June 2021
}

\begin{abstract}
The bunch moth, Tirathaba mundella, is one of the leading pests in oil palm estates established on peatland. Severely infested male inflorescences usually would fail reaching anthesis. Reduction in the number of inflorescences at anthesis stage would suggest less food source and breeding ground for oil palm pollinating weevils, Elaeidobius kamerunicus, thus, affecting the fruiting percentage of oil palm and its yield. Despite to be less detrimental to the environment, biopesticide usages in the field is losing favour due to its slower rate of killing compared with that by conventional chemical pesticides, shorter persistence in the environment and susceptibility to unfavourable environmental conditions. The use of high host specificity chemical pesticides, such as chlorantraniliprole and chromafenozide are gaining popularity in pest management regimes. In this study, the optimum dose for chlorantraniliprole and chromafenozide in controlling T. mundella was assessed to provide valuable information for sustainable oil palm pest management. Several dosages of pesticide were evaluated for their effectiveness against T. mundella in a 7-year-old oil palm estate for six months. Based on the results obtained, application of $30 \mathrm{~g}$ or $40 \mathrm{~g}$ active ingredient (a.i.) per ha chlorantraniliprole were recommended to provide the longest protection period. To make plan for an effective pest management that could reduce material and labour cost per ha as well as the risks in developing pesticide resistance among pest, $30 \mathrm{~g}$ a.i per ha of chlorantraniliprole is recommended to be rotated with $25 \mathrm{~g}$ a.i. per ha chromafenozide for a total of four rounds in a year.
\end{abstract}

Keywords: Chlorantraniliprole, Chromafenozide, Tirathaba mundella

Copyright: This is an open access article distributed under the terms of the CC-BY-NC-SA (Creative Commons Attribution-NonCommercial-ShareAlike 4.0 International License) which permits unrestricted use, distribution, and reproduction in any medium, for non-commercial purposes, provided the original work of the author(s) is properly cited.

\section{INTRODUCTION}

Tirathaba mundella Walker is a predominant pest infesting both inflorescence and fruit bunches of oil palm Elaeis guineensis in Malaysia, causing fruit deformation and bunch abortion in cases of severe infestation. At present, the common method to control T. mundella in the field is using biopesticides that is known to have less detrimental effect on beneficial insect. However, chemical insecticides that are pollinating-weevil friendly such as chlorantraniliprole and chromafenozide (Su et al., 2020) are gaining popularity because they display better pest controlling effect than biopesticide. Since the efficacy of $B$. thuringiensis pesticides can be affected by a number of environmental factors such as sunlight, temperature, pest density and presence of associated filter feeding non-target organisms
(Dunkle \& Shasha, 1989), chlorantraniliprole and chromafenozide are expected to become an important component in very near future pest management regimes. However, the optimum and cost-effective rate of both chlorantraniliprole and chromafenozide in controlling T. mundella in the field has yet to be established. Two field experiments were therefore initiated to obtain the optimal dosage of chlorantraniliprole with biological insecticide as a baseline control for assessing the efficacy of the different dosages of chromafenozide and chlorantraniliprole against oil palm bunch moth, $T$. mundella Walker.

Chlorantraniliprole is an anthranilic diamides insecticide and chromafenozide is an insect growth regulator. Su (2016) recommended both of these pesticides to control T. mundella in oil palm because 
they are found to be pollinating weevil, Elaeidobius kamerunicus friendly.

In this study, the optimal dosage of chromafenozide in rotation with chlorantraniliprole were determined. Both chromafenozide and chlorantraniliprole were used in rotation to slow down the development of insecticide resistance. Both insecticides have different mode of action. Chromafenozide is classified as an insect growth regulator that disturbs normal growth and insect development, which in time can kill the insect $(\mathrm{Yu}$, 2014). Chlorantraniliprole is a ryanodine receptor modulator that activates ryanodine receptors to stimulate the uncontrollable release of calcium and, as a result, the targeted insects would experience muscle paralysis and ultimately death of the insect (Yu, 2014).

In this study, two additional insecticides namely Bacillus thuringiensis-based insecticide, and indoxacarb were included in the evaluation to serve as positive control. All the insecticides tested were known to be friendly to oil palm natural pollinators, E. kamerunicus. The use of these insecticides in $T$. mundella management is therefore highly recommended. This paper presented the optimum and cost-effective rate of chlorantraniliprole and the optimum dosage of chromafenozide to be used in rotation with chlorantraniliprole.

\section{MATERIALS AND METHODS}

\section{Experimental Site and Design}

Two experiments were conducted to determine (1) the optimal dosage of chlorantraniliprole used to control T. mundella and (2) the optimum dosage of chromafenozide to be used in rotation with chlorantraniliprole. Both experiments were carried out in a 7-year-old oil palm estate established on peat. The design of the experiment was complete randomised block design with four replicates. Oil palms were planted $8.5 \mathrm{~m}$ apart in a triangular pattern in the estate. Each planting row consisted of 11 palms, and each planting block consisted of four rows of palms. A field drain separated each block. For each treatment, a block that consists of four rows of palms was considered as a replicate. With this planting layout, the middle two rows of palms (22 palms) in each block were selected as sampling palms while the balance change to remaining two rows which were grown next to the field drain were treated as guard palms. The size of the experimental plot for optimal dosage of chlorantraniliprole was 8.75 ha, whereas the experimental plot size for determining the optimum dosage of chromafenozide in rotation with optimal dosage of chlorantraniliprole was 3.75 ha.

\section{Optimal Dosage of Chlorantraniliprole}

In the experiment to determine the optimal dosage of chlorantraniliprole, two types of insecticides were tested and compared to chlorantraniliprole, which were $B$. thuringiensis-based insecticide, and indoxacarb. B. thuringiensis-based insecticide and indoxacarb were chosen as they are among the common pesticides used in Sarawak oil palm estates. A total of seven treatments were assessed, consisted of a negative control, four dosages of $34.9 \% \mathrm{w} / \mathrm{w}$ chlorantraniliprole (10 g active ingredient (a.i.) per ha, $20 \mathrm{~g}$ a.i. per ha, $30 \mathrm{~g}$ a.i. per ha and $40 \mathrm{~g}$ a.i. per ha), one recommended dosage $\left(6.6 \times 10^{6}\right.$ I.U) of $B$. thuringiensis-based insecticide with 17,600 I.U/mg and one recommended dosage ( $45 \mathrm{~g}$ a.i. per ha) of indoxacarb. The rate used as shown in Table 1.

\section{Optimal Dosage of Chromafenozide in Rotation with Chlorantraniliprole}

Three different dosages ( $25 \mathrm{~g}$ a.i. per ha, $37 \mathrm{~g}$ a.i. per ha and $50 \mathrm{~g}$ a.i. per ha) of chromafenozide were tested with optimal dosage (30 g a.i. per ha) of chlorantraniliprole. The pesticide application regimes were set with only four rounds application in a year against oil palm bunch moth. Four rounds of pesticide applications are regarded as economically feasible. The insecticide application rate and rotation mechanism tested are shown in Table 2 and Table 3.

\section{Evaluation of Efficacy of Insecticide Application}

Prior to the application of insecticides, the infestation status of T. mundella in all trial plots was assessed to get the baseline data. The field census was carried out every month post-treatment for of six months to determine optimal dosage for chlorantraniliprole; whereas for experiment to determine optimal dosage of chromafenozide, the census was conducted monthly for a period of twelve months. The pest infestation census was carried out based on the parameters as described in Su et al. (2020). The total number of clean fruit bunches, moderately infested fruit bunches and severely infested fruit bunches were recorded. 
Table 1. Insecticides application rate for chlorantraniliprole optimal dosage trial

\begin{tabular}{|c|c|c|c|c|}
\hline Treatment & $\begin{array}{l}\text { Trade name / } \\
\text { Product }\end{array}$ & $\begin{array}{c}\text { a.i. Rate of } \\
\text { product per ha }\end{array}$ & $\begin{array}{c}\text { Rate per } 16 \text { litres of } \\
\text { water }\end{array}$ & $\begin{array}{c}\text { Product rate per } \\
\text { ha }\end{array}$ \\
\hline Absolute control (T1) & - & - & - & - \\
\hline $\begin{array}{c}34.9 \% \mathrm{w} / \mathrm{w} \\
\text { Chlorantraniliprole (T2) }\end{array}$ & $\begin{array}{l}\text { Dupont Altacor } \\
34.9 \mathrm{WG}\end{array}$ & $10 \mathrm{~g}$ & $1.60 \mathrm{~g}$ & $28.70 \mathrm{~g}$ \\
\hline $\begin{array}{c}34.9 \% \mathrm{w} / \mathrm{w} \\
\text { Chlorantraniliprole (T3) }\end{array}$ & $\begin{array}{l}\text { Dupont Altacor } \\
34.9 \mathrm{WG}\end{array}$ & $20 \mathrm{~g}$ & $3.00 \mathrm{~g}$ & $57.30 \mathrm{~g}$ \\
\hline $\begin{array}{c}34.9 \% \mathrm{w} / \mathrm{w} \\
\text { Chlorantraniliprole (T4) }\end{array}$ & $\begin{array}{l}\text { Dupont Altacor } \\
34.9 \mathrm{WG}\end{array}$ & $30 \mathrm{~g}$ & $4.60 \mathrm{~g}$ & $85 \mathrm{~g}$ \\
\hline $\begin{array}{c}34.9 \% \mathrm{w} / \mathrm{w} \\
\text { Chlorantraniliprole (T5) }\end{array}$ & $\begin{array}{l}\text { Dupont Altacor } \\
34.9 \mathrm{WG}\end{array}$ & $40 \mathrm{~g}$ & $5.20 \mathrm{~g}$ & $115 \mathrm{~g}$ \\
\hline $\begin{array}{c}\text { Bacillus thuringiensis } \\
\text { (T6) }\end{array}$ & $\begin{array}{c}\text { Dipel ES } \\
\text { 17,600 I.U/mg }\end{array}$ & $6.6 \times 10^{6} \mathrm{I} . \mathrm{U}$ & $30 \mathrm{ml}$ & $562 \mathrm{ml}$ \\
\hline $\begin{array}{c}30.0 \% \text { w/w Indoxacarb } \\
\text { (T7) }\end{array}$ & Tatum & $45 \mathrm{~g}$ & $8.0 \mathrm{~g}$ & $150 \mathrm{~g}$ \\
\hline
\end{tabular}

Note: Recommended dosage per $16 \mathrm{~L}$ water is based on spray volume of $300 \mathrm{~L} / \mathrm{ha}$.

Table 2. Insecticides application rate and rotation schedule for chromafenozide optimal rates trial

\begin{tabular}{|c|c|c|c|c|}
\hline Treatment & $\begin{array}{c}\text { Product } \\
\text { rate per ha }\end{array}$ & $\begin{array}{l}\text { a.i. of product } \\
\text { per ha }\end{array}$ & Rotation schedule & Total rounds per year \\
\hline $\begin{array}{l}\text { Chlorantraniliprole } \\
34.9 \% \mathrm{w} / \mathrm{w} \text { rotated } \\
\text { with Chromafenozide } \\
4.9 \% \mathrm{w} / \mathrm{w}(\mathrm{T} 1)\end{array}$ & $\begin{array}{c}85 \mathrm{~g} \\
500 \mathrm{ml}\end{array}$ & $\begin{array}{l}30.0 \mathrm{~g} \\
25.0 \mathrm{~g}\end{array}$ & $\begin{array}{l}\text { One round at interval of } \\
\text { four months rotated with } \\
\text { one round at interval of } \\
\text { three months. }\end{array}$ & 4 \\
\hline $\begin{array}{l}\text { Chlorantraniliprole } \\
34.9 \% \mathrm{w} / \mathrm{w} \text { rotated } \\
\text { with Chromafenozide } \\
4.9 \% \mathrm{w} / \mathrm{w}(\mathrm{T} 2)\end{array}$ & $\begin{array}{c}85 \mathrm{~g} \\
750 \mathrm{ml}\end{array}$ & $\begin{array}{l}30.0 \mathrm{~g} \\
37.0 \mathrm{~g}\end{array}$ & $\begin{array}{l}\text { One round at interval of } \\
\text { four months rotated with } \\
\text { one round at interval of } \\
\text { three months. }\end{array}$ & 4 \\
\hline $\begin{array}{l}\text { Chlorantraniliprole } \\
34.9 \% \text { w/w rotated } \\
\text { with Chromafenozide } \\
4.9 \% \mathrm{w} / \mathrm{w}(\mathrm{T} 3)\end{array}$ & $\begin{array}{c}85 \mathrm{~g} \\
1000 \mathrm{ml}\end{array}$ & $\begin{array}{l}30.0 \mathrm{~g} \\
50.0 \mathrm{~g}\end{array}$ & $\begin{array}{l}\text { One round at interval of } \\
\text { four months rotated with } \\
\text { one round at interval of } \\
\text { three months. }\end{array}$ & 4 \\
\hline
\end{tabular}


Table 3. Rotation of insecticides application for chromafenozide optimal rates trial

\begin{tabular}{|c|c|c|c|c|}
\hline \multirow[b]{2}{*}{ Treatment } & \multicolumn{4}{|c|}{ Rotation Intervals for Pesticide Application } \\
\hline & November 18 & March 19 & June 19 & October 19 \\
\hline $\begin{array}{l}85 \mathrm{~g} \text { Chlorantraniliprole } \\
34.9 \% \mathrm{w} / \mathrm{w} \text { rotated with } \\
500 \mathrm{ml} \text { Chromafenozide } \\
4.9 \% \mathrm{w} / \mathrm{w}(\mathrm{T} 1)\end{array}$ & Chlorantraniliprole & Chromafenozide & Chlorantraniliprole & Chromafenozide \\
\hline $\begin{array}{l}85 \mathrm{~g} \text { Chlorantraniliprole } \\
34.9 \% \mathrm{w} / \mathrm{w} \text { rotated with } \\
750 \mathrm{ml} \text { Chromafenozide } \\
4.9 \% \mathrm{w} / \mathrm{w}(\mathrm{T} 2)\end{array}$ & Chlorantraniliprole & Chromafenozide & Chlorantraniliprole & Chromafenozide \\
\hline $\begin{array}{l}85 \mathrm{~g} \text { Chlorantraniliprole } \\
34.9 \% \mathrm{w} / \mathrm{w} \text { rotated with } \\
1000 \mathrm{ml} \text { Chromafenozide } \\
4.9 \% \mathrm{w} / \mathrm{w}(\mathrm{T} 3)\end{array}$ & Chlorantraniliprole & Chromafenozide & Chlorantraniliprole & Chromafenozide \\
\hline
\end{tabular}

\section{Statistical Analysis}

Data for both trials were subjected to square root transformation prior to analysis of variance (ANOVA) using statistical analysis system (SAS) version 8.2 (SAS Institute Inc., Cary, NC, USA). The means percentage of infestation were separated using Duncan New Multiple Range Test at a significant level of $\mathrm{p}=0.05$.

\section{RESULTS}

\section{Optimal Dosage of Chlorantraniliprole Against Oil Palm Bunch Moth, T. mundella}

All treatments started with no significant difference in their mean percentage of clean fruit bunches as compared to the negative control in week 0 (Figure 1). After one month of treatment, the trial plots treated with B. thuringiensis insecticide, chlorantraniliprole and indoxacarb had outperformed the control plot with significantly higher mean percentage of clean bunches recorded (Figure 1) and reduced percentage of severely infested fruit bunches just a month after the application (Figure 2). The mean percentage of clean to light fruit bunches in all the treated fields were significantly higher than the negative control plot which had only $16.06 \%$ protected in week 4 . This showed the insecticides' protection effect against $T$. mundella. In week 8, two months after treatment, the mean percentage of clean to light fruit bunches in plots treated with different concentrations of chlorantraniliprole increased further and offered more than $70 \%$ protection, which was significantly higher than the control, B. thuringiensis treated and indoxacarb treated plots. In week 8, plots treated with $B$. thuringiensis were also better than the control with higher mean percentage of clean to light fruit bunches. However, from week 12 onwards, there were no significant difference in mean percentage of clean to light fruit bunches among $B$. thuringiensis treated, indoxacarb treated plots and the negative control (Figure 1). But chlorantraniliprole treated plots continued to yield higher percentage of clean to light fruit bunches than other treatments.

For plots treated with $30 \mathrm{~g}$ and $40 \mathrm{~g}$ chlorantraniliprole, the mean percentage of clean to light fruit bunches were significantly higher than plots treated with either $10 \mathrm{~g}$ chlorantraniliprole or 20 $\mathrm{g}$ chlorantraniliprole. There were no significant differences in their performance between $10 \mathrm{~g}$ and 20 $\mathrm{g}$ of chlorantraniliprole as well as $30 \mathrm{~g}$ and $40 \mathrm{~g}$ of chlorantraniliprole. When reaching week 24 , plots treated with $40 \mathrm{~g}$ chlorantraniliprole per ha had the highest percentage of clean to light fruit bunches among all the treatments. Oil palm plots treated with $40 \mathrm{~g}$ chlorantraniliprole per ha continually produced above $60 \%$ of clean to light fruit bunches throughout the six months monitoring period (Figure 1). Coming second is the field plots treated with $30 \mathrm{~g}$ chlorantraniliprole, which had above $60 \%$ of clean to light fruit bunches until week 20 before declined slightly to $52 \%$ in week 24 . However, there was no significant differences in overall percentage of moderately infested fruit bunches (Figure 3), therefore it will not be included to assess the insecticides protection efficacy. 


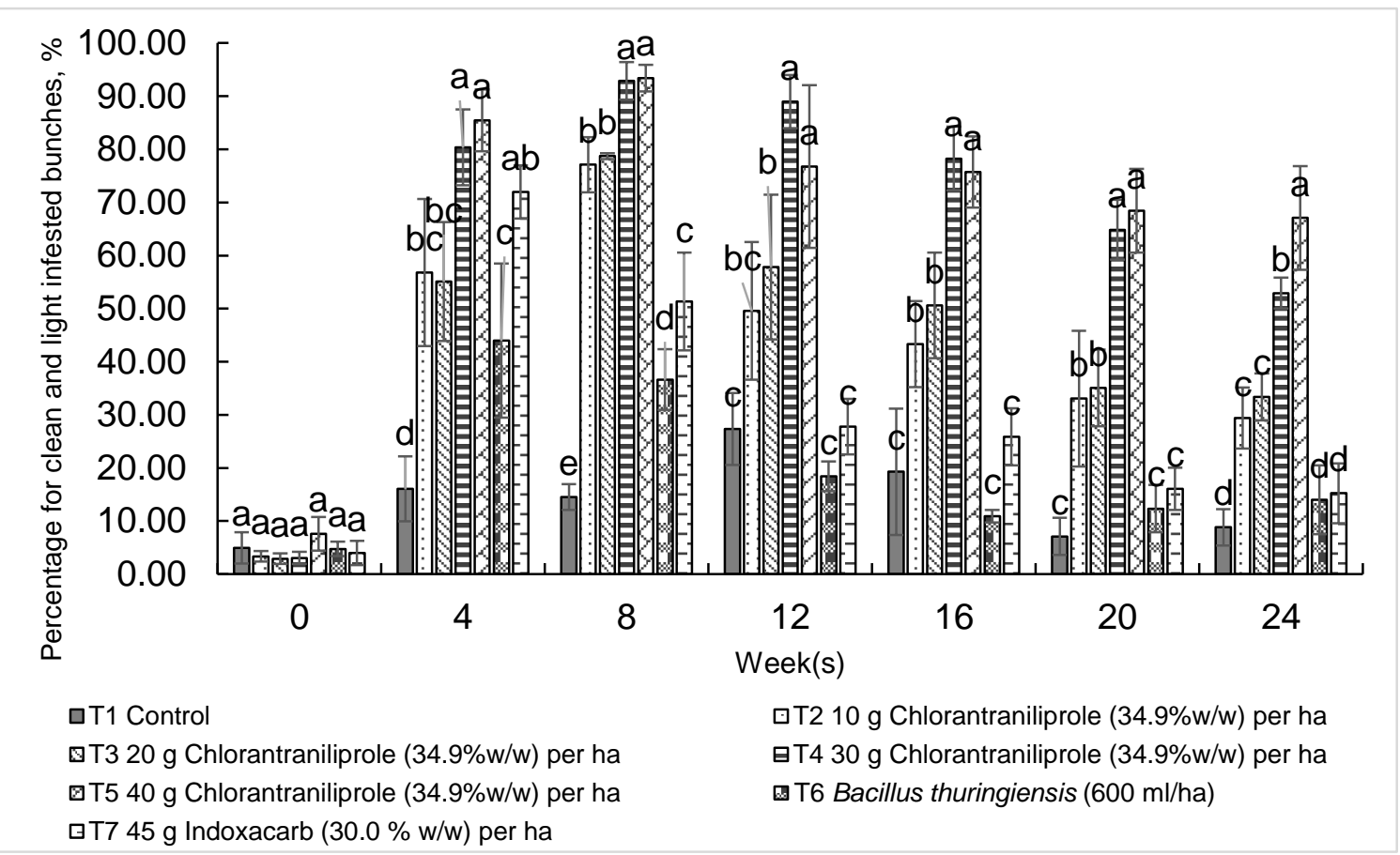

Figure 1. Mean percentage of clean fruit bunches for chlotantraniliprole optimal dosage trial. Means with the same letters within sampling period are not significantly different according to DNMRT at $\mathrm{p}=0.05$. The vertical bars represent the standard error of means for four replicates

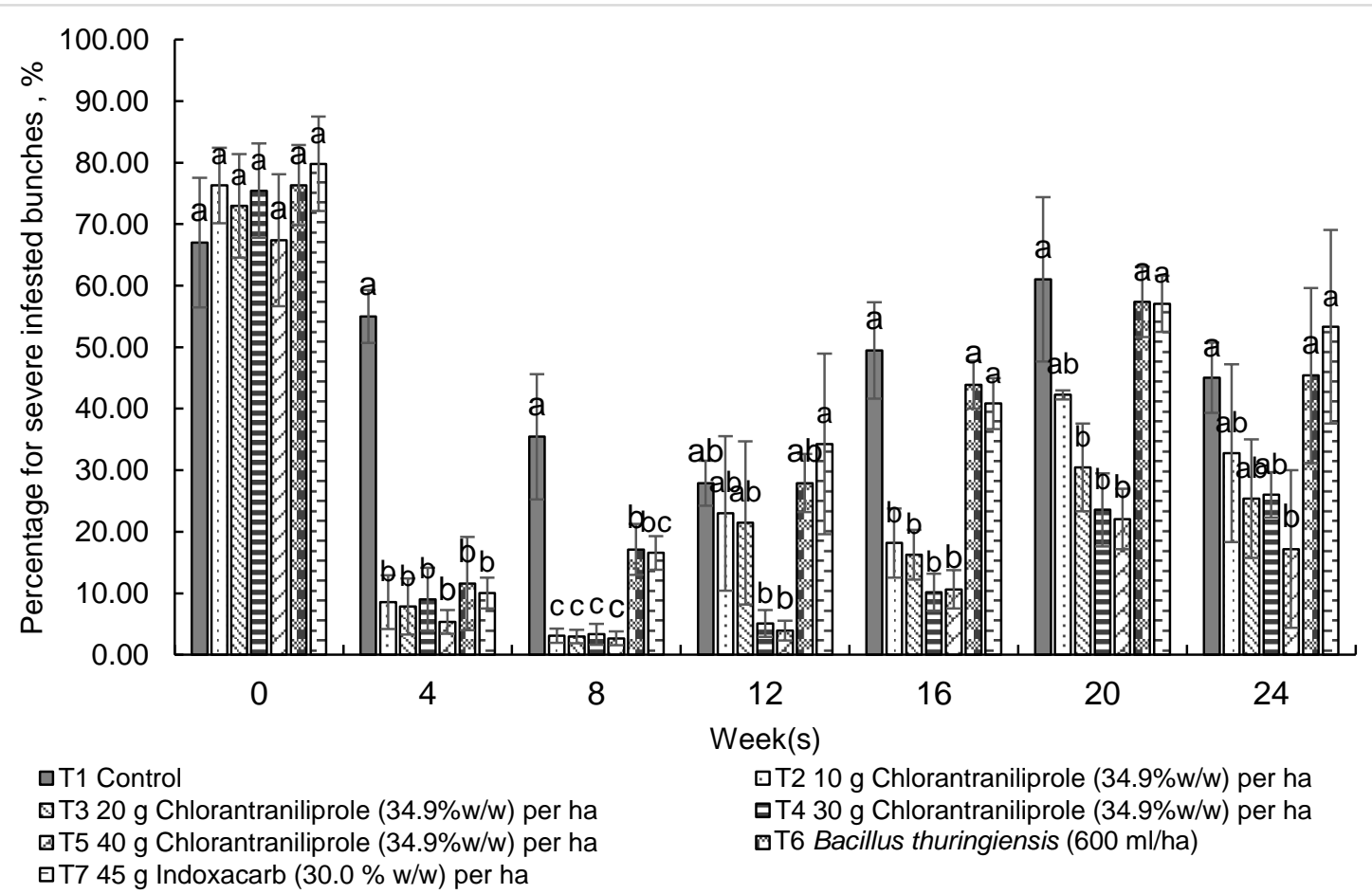

Figure 2. Mean percentage of severely infested fruit bunches for chlorantraniliprole optimal dosage trial. Means with the same letters within sampling period are not significantly different according to DNMRT at $\mathrm{p}=0.05$. The vertical bars represent the standard error of means for four replicates 


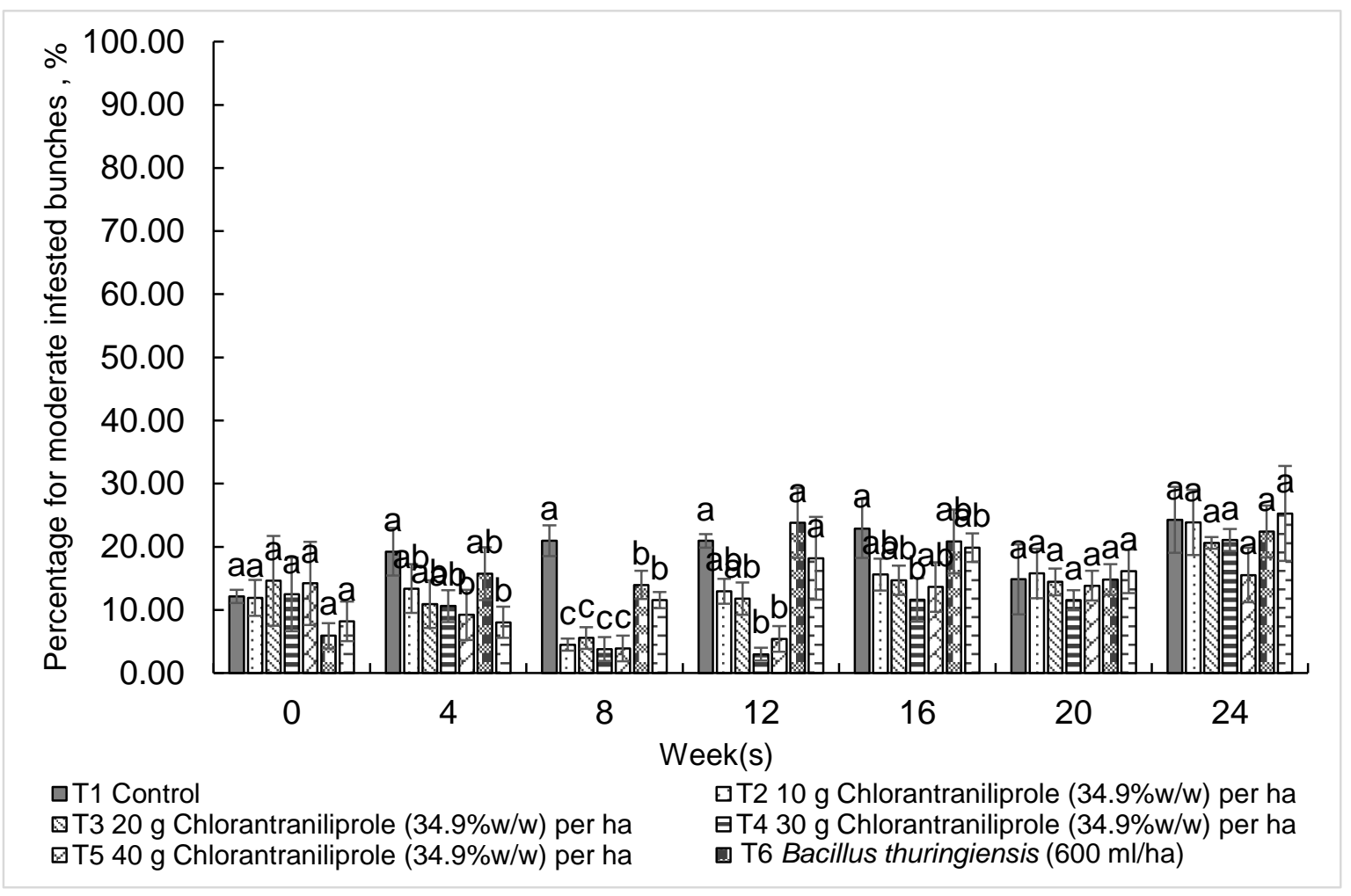

Figure 3. Mean percentage of moderately infested fruit bunches for chlorantraniliprole optimal dosage trial. Means with the same letters within sampling period are not significantly different according to DNMRT at $\mathrm{p}=0.05$. The vertical bars represent the standard error of means for four replicates

For mean percentage of severely infested fruit bunches, there was no significant difference among all the treatments and negative control in week 0 . The mean percentage of severely infested fruit bunches in control plots were fluctuated in the range of $28 \%$ to $67 \%$ during the six months of assessment. A substantial reduction in the percentage of severely infested fruit bunches was noted in all plots treated with insecticides in week 4 and 8 . The mean percentage of severely infested fruit bunches in all the treated plots were significantly lower than negative control during the first and second month after treatment. However, from week 12 onwards, there was no significant difference in the mean percentage of severely infested fruit bunches obtained between $B$. thuringiensis treated plots and the negative control plots. For indoxacarb treated plots, significantly lower mean percentage of severely infested fruit bunches as compared to negative control was recorded in week 4 and week 8. However, from week 12 onwards, there was no significant difference in the mean percentage of severely infested fruit bunches obtained between indoxacarb treated plots and the negative control
(Figure 2).

On contrast, chlorantraniliprole outplays the other treatments with relatively low mean percentage of severely infested fruit bunches throughout the six months monitoring period. For trial plots treated with $40 \mathrm{~g}$ chlorantraniliprole, the mean percentage of severely infested fruit bunches were persistently lower than the control plots from week 4 onwards until the end of month six. Plots treated with $30 \mathrm{~g}$ and $40 \mathrm{~g}$ of chlorantraniliprole per ha outperformed the rest of the treatments in week 12 and when reached week 24, trial plots treated with $40 \mathrm{~g}$ of chlorantraniliprole per ha had the lowest mean percentage of severely infested fruit bunches (Figure 2). Moreover, the one-time application with $40 \mathrm{~g}$ chlorantraniliprole per ha offered significant better protection for a period of six months against oil palm bunch moth than the other treatments. It reduced the number of severely infested fruit bunches (Figure 2) and increased number of clean to light fruit bunches (Figure 1). The duration of pest control exhibited by chlorantraniliprole in this trial is far more prolonged as compared to indoxacarb and $B$. thuringiensis. 


\section{The Efficacy of Different Dosages of Chromafenozide Rotated with Chlorantraniliprole}

Chlorantraniliprole at $30 \mathrm{~g}$ a.i. per ha (equivalent to $85 \mathrm{~g} / \mathrm{ha}$ of chlorantraniliprole $34.9 \% \mathrm{w} / \mathrm{w}$ ) was used in rotation with chromafenozide at different dosage. The mean percentage of clean fruit bunches increased after a month of treatment in all three treatments tested (Figure 4). Two months after treatment, mean percentage of clean fruit bunches in Treatment 1 increased further to $70 \%$ while Treatment 2 and 3 at $64 \%$ and $57 \%$ respectively. Mean percentage of clean to light fruit bunches in Treatment 3 was significantly lower as compared to Treatment 1 . However, from week 12 onwards, until week 52, there was no significant difference between all the treatments for mean percentage of clean to light fruit bunches (Figure 4).

Overall, one round of chlorantraniliprole applied in week 0 managed to maintain the mean percentage of clean to light fruit bunches over $60 \%$ for continuous 4 months before rotated with another round of chromafenozide in week 16 . In week 20 , one month after chromafenozide was applied, the mean percentage of clean to light fruit bunches increased further to more than $80 \%$. The mean percentage of clean to light fruit bunches maintained at $60 \%$ to $80 \%$ from week 16 to week 28 for all the treatments. The third round of insecticide application using chlorantraniliprole (week 28) pushed up the overall mean percentage of clean fruit bunches to more than $80 \%$ and the number maintained at $75 \%$ in week 40 and week 44 . The last round of insecticide application by adopting chromafenozide in week 44 managed to maintain the mean percentage of clean fruit bunches above 70\% except for Treatment 3.

For mean percentage of moderately infested fruit bunches, there was no significant difference among all the three treatments throughout 52 weeks of monitoring period. The mean percentage of moderately infested fruit bunches in Treatment 1 fluctuated from as low as $10 \%$ in week 20 to as high as $26 \%$ in week 4 . Treatment 2 on the other hand contained mean percentage of moderately infested fruit bunches from as low as $12 \%$ to as high as $26 \%$. Similar trend was also observed in Treatment 3.

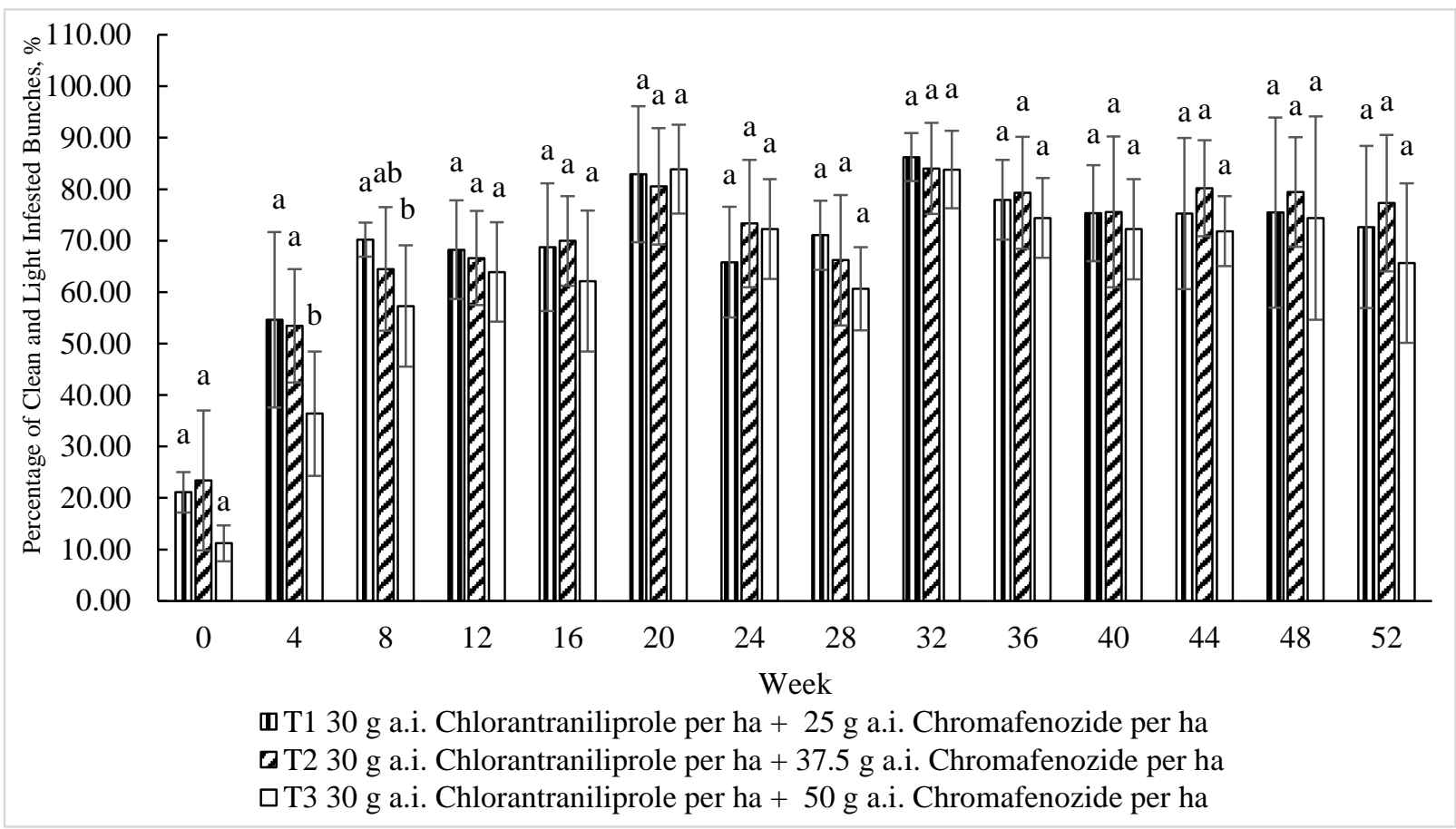

Figure 4. Mean percentage of clean to light fruit bunches for chromafenozide optimal dosage trial. Means with the same letters within sampling period are not significantly different according to DNMRT at $\mathrm{p}=0.05$. The vertical bars represent the standard error of means for four replicates 
Before treatment imposed (week 0), the mean percentage of severely infested fruit bunches fluctuated around $50 \%$ to $70 \%$, which is not significantly different between all the treatments. However, in week 4 , the mean percentage of severely infested fruit bunches reduced substantially to $19 \%, 19 \%$ and $39 \%$ for Treatment 1, Treatment 2 and Treatment 3 , respectively. In week 8 , the mean percentage of severely infested fruit bunches in all the three treatments reduced further and maintained below $15 \%$ until week 16 , before the second round of insecticide chromafenozide was applied (Figure 5 ). In week 20, one month after the second round of insecticide application, the mean percentage of severely infested fruit bunches in all the three treatments reduced further to below $10 \%$ and maintained through week 24 before increased slightly in week 28 . On the other hand, mean percentage of severely infested fruit bunches in both
Treatment 1 and Treatment 2, maintained below 10\% from week 32 until week 52, where chlorantraniliprole and chromafenozide were applied in week 28 and week 44 respectively. However, for Treatment 3, where $30 \mathrm{~g}$ chlorantraniliprole was rotated with $50 \mathrm{~g}$ chromafenozide per ha, the mean percentage of severely infested fruit bunches only reduced to below $10 \%$ in week 32 and week 48 . Nevertheless, there was no significant difference among all the treatments on mean percentage of severely infested fruit bunches from week 4 to week 52.

Comparing all the three different dosages of chromafenozide applied, the mean percentage of clean (Figure 4), moderately infested (Figure 6) and severely infested fruit bunches (Figure 5) were no significant different throughout 52 weeks of monitoring period.

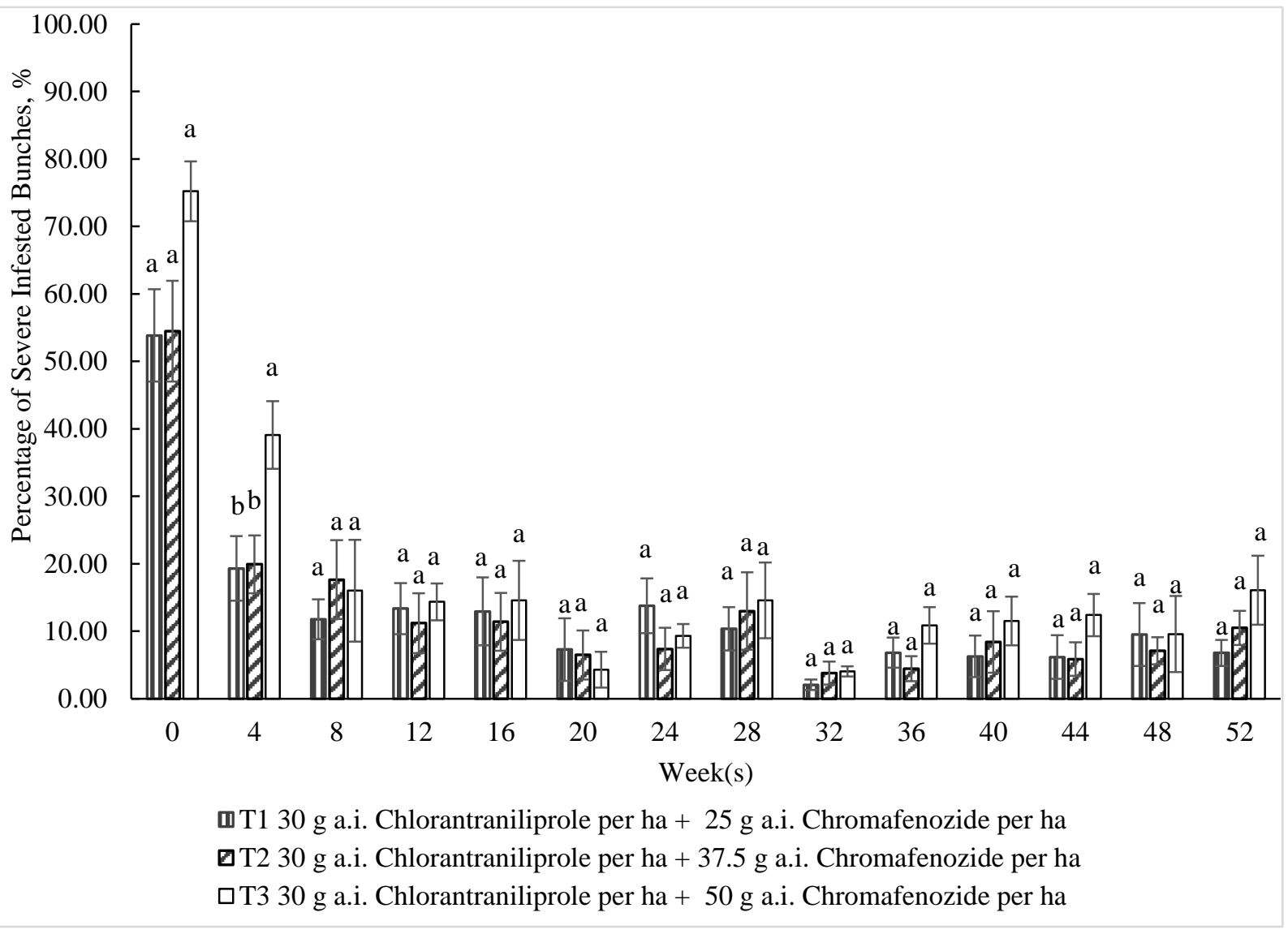

Figure 5. Mean percentage of severely infested fruit bunches for chromafenozide optimal dosage trial. Means with the same letters within sampling period are not significantly different according to DNMRT at $\mathrm{p}=0.05$. The vertical bars represent the standard error of means for four replicates 


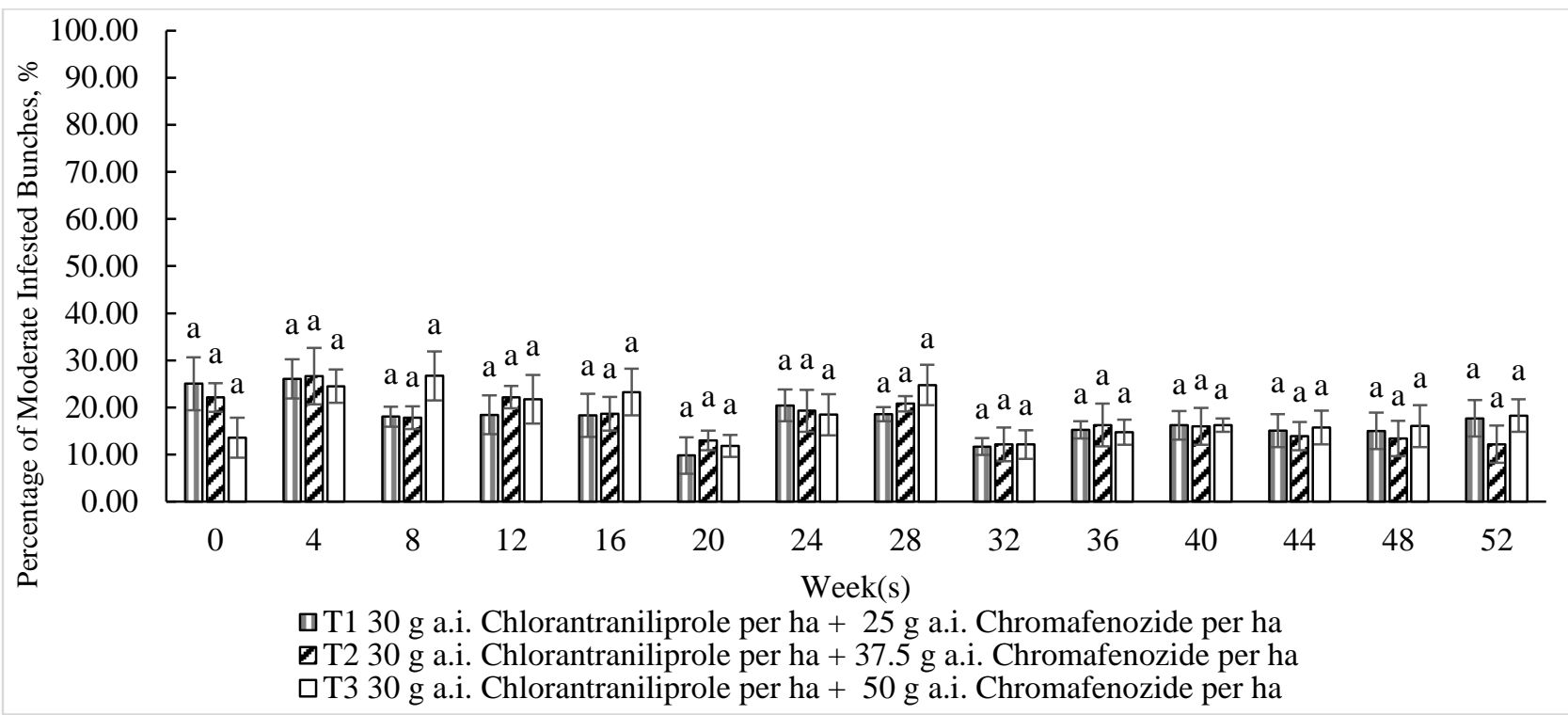

Figure 6. Mean percentage of moderately infested fruit bunches for chromafenozide optimal dosage trial. Means with the same letters within sampling period are not significantly different according to DNMRT at $p=0.05$. The vertical bars represent the standard error of means for four replicates

\section{DISCUSSION}

\section{Optimal Dosage of Chlorantraniliprole Against Oil Palm Bunch Moth, Tirathaba mundella}

Both $B$. thuringiensis insecticide and indoxacarb treatments increased the percentage of clean fruit bunches and declined the percentage of severely infested fruit bunches. However, the effect did not last for three months. The residue effect faded on the third month after application. Even though, biological insecticide, $B$. thuringiensis was introduced to the oil palm plantation to manage pest as it is ecologically friendly and demonstrate non toxicity against human, yet, the effectiveness of $B$. thuringiensis in controlling oil palm bunch moth was questionable as observed in this study. The rapidly waning insecticide effect of $B$. thuringiensis would require more frequent application to ensure the pest infestation can be effectively suppressed. Saharul et al. (2017) had suggested follow up applications of $B$. thuringiensis to be executed 34 and 84 days after treatment to prevent rapid re-emergence of pest population. Being a biological insecticide, the efficacy of $B$. thuringiensis is affected by the length of exposure to ultra violet or solar radiation in the field (Becker et al., 1992). The half-life of $B$. thuringiensis to solar radiation has been estimated at 3.8 hour (Dunkle \& Shasha, 1989).

Bacillus thuringiensis also asserted its insecticide properties much slower than the chemical insecticides. Crystalline proteinaceous inclusions or the protoxins of $B$. thuringiensis need to be ingested by the targeted pest, or more precisely the target larvae prior the insecticide can take effect. Protoxin is in its inactivated form, upon ingestion, protoxins will be activated through a series of proteolytic process where the protoxins are solubilized in the alkaline mid gut fluid with $\mathrm{pH}$ more than 10 , then reduce into toxins by specific proteases (Saxena et $a l ., 2010)$. Once activated, the active toxins interact with receptors on mid-gut epithelial cells, where the toxins form pores and destroy insects' cells by osmotic lysis (Deepak et al., 2001). Thus, it is a process that would take at least a few days to a week. For area with severe outbreak of oil palm bunch moth, application of B. thuringiensis would not aid in suppressing the pest population even with multiple repeated applications.

Indoxacarb on the other hand attested slightly higher toxicity against oil palm bunch moth than $B$. thuringiensis. However, poorer performance as compared to chlorantraniliprole. Indoxacarb, methyl (S)-N-[7-chloro-2,3,4a,5-tetrahyro-4a-(methoxycarbonyl) indeno [1,2-e] [1,3,4] oxadiazin-2-ylcarbonyl]-4'(trifluoromethoxy) carbanilate (Szpyrka et al., 2017), which belongs to the oxadiazine group is a broad spectrum, non-systemic and synthetic organophosphate replacement insecticide, environmental compatibility and safety to non-target organisms (Wing et al., 2000; Spomer et al., 2009). Indoxacarb is touted by the industry as a reduced-risk 
insecticide, where target insects were affected through direct absorption into the insects' body or via ingestion of the treated fruit or foliage (Adriana, 2003). The mode of action of indoxacarb is by inhibiting the flow of sodium ions into the nerve cells of the target insects. The flow of sodium ions is essential for nervous system to function properly. Disruption of these channels causes tremors, cessation of feeding, paralysis and eventually death of the insect pests (Brugger, 1997; Parthiban et al., 2016).

Indoxacarb is not harmful to oil palm natural pollinators, Elaeidobius kamerunicus $(\mathrm{Su}, 2016)$ and its mode of action which differ from chlorantraniliprole and $B$. thuringiensis, has no known cross resistance with other organophosphates, carbamate and pyrethroids were among the reasons why it was chosen to be tested in this study. However, indoxacarb also exhibited short pesticides effect period and the use of it solely to curb T. mundella infestation is not recommended.

In general, all insecticides used in this study offered some extend of protection to all the oil palms against T. mundella. However, the results of optimal dosage of chlorantraniliprole trial demonstrated that chlorantraniliprole displayed the highest effectiveness in protecting oil palm from oil palm bunch moth. Chlorantraniliprole outperformed $B$. thuringiensis and indoxacarb, which yielded more clean to light fruit bunches than all other treatments. Chlorantraniliprole, is an anthranilic diamide insecticide developed by Du Pont de Nemours and Company, Inc. Chlorantraniliprole is effective against chewing insect pest primarily through ingestion and secondarily by contact through a very specific mode of action. Chlorantraniliprole activates the ryanodine receptors of the target pests vis stimulating the release of calcium from internal stores in the sarcoplasmic reticulum of muscle cells. This results impaired regulation, paralysis and ultimately death of the target insect (Lahm et al., 2005; Lahm et al., 2007; Axel et al., 2009; Gustavo et al., 2015).

The $30 \mathrm{~g}$ and $40 \mathrm{~g}$ chlorantraniliprole per ha with satisfactory control on oil palm bunch moth, $T$. mundella Walker as shown in this trial was a relatively low dosage required as compared to other fruit trees, vegetable crops, grapes and potatoes which needed $60 \mathrm{~g}$ chlorantraniliprole per ha to give considerable protection against pest (Axel et al., 2009). The lower dosage needed to control oil palm bunch moth indicates the high effectiveness of chlorantraniliprole in controlling T. mundella and makes it an attractive choice as it will reduce the cost of pest management.

The longer pest control effect of the chlorantraniliprole noted in this study is consistent with the observation reported by Malaysia Palm Oil Board that plots treated with chlorantraniliprole could suppress $T$. mundella population at low level for more than 50 days after the last application (Saharul et al., 2017). Longer lasting of chlorantraniliprole could relate to its high resistance to photo-degradation, rainfast nature and ability to move trans-laminar in the plant system as reported by Temple et al. (2009) and Chua et al. (2010). With this feature, chlorantraniliprole certainly will have advantage in region with no shortage of sunshine and high rainfall (2,500 $\mathrm{mm}$ per year in Sarawak).

\section{The Efficacy of Different Dosages of Chromafenozide Rotated with Chlorantraniliprole}

The reason chlorantraniliprole was chosen to rotate with chromafenozide in this study was due to the fact that it is designated as a reduced-risk pesticide by the United States Environment Protection Agency, which has demonstrated low intrinsic toxicity on honey bees and bumblebees (Axel et al., 2009) and its high potent effect on $T$. mundella as demonstrated in the results obtained from optimal dosage of chlorantraniliprole trial. The very low mammalian toxicity with a favourable eco-toxicological profile, no cross-resistance issue with other conventional organophosphate and carbamate pesticides as well as highly efficacious against lepidopteran species at relatively low application rates has made chlorantraniliprole an ideal candidate for integrated T. mundella management in peat.

Chromafenozide, as an insect growth regulator is the most potent non-steroidal ecdysteroid agonist (Ahmed et al., 2015; Saleh \& Abdel-Gawad, 2018) of the dibenzoylhydrazine compound against a wide range of lepidopteran larvae namely Noctuidae, Pyralidae, Pieridae and Tortricidae (Ghoneim \& Tanani, 2017). On the other hand, chromafenozide is relatively weak or inactive against Diptera and Coleoptera families and low toxicity profile towards mammals, birds, fishes as well as non-target arthropods such as predators, insect pollinators and parasitoids (Mikio et al., 2006; Hadi et al., 2008). Therefore, chromafenozide had the least harmful effect on the survival of newly emerged oil palm pollinator weevils. The narrow spectrum of 
insecticidal activity of chromafenozide makes it an excellent candidate for integrated pest management programmes. The repeating usage and the use of antagonistis mixtures of chemicals on season-long pest control would exacerbates pest resistance problem. Therefore, adoption of rotation mechanism by alternating different chemicals with different mode of actions are useful strategies to breakdown insecticide resistance problems (Ghoneim et al., 2012). The results obtained from optimal dosage of chromafenozide rotated with chlorantraniliprole also revealed that chromafenozide with diferent mode of action from chlorantraniliprole would serve as a potential alternative insecticide in chemical rotation mechanism in controlling oil palm bunch moth, $T$. mundella in a more sustainable way. This application method applied in the oil palm plantation with severe pest outbreak would indirectly contribute to the pest resistant management where problems associated with resistant oil palm bunch moth strain to the available insecticides would not surface in near future.

In lepidopteran insects, the steroid hormone 20hydroxyecdysone functions as a generalized systemic signal coordinating critical developmental events of embryogenesis, larval molting, metamorphosis and reproduction mechanism. When chromafenozide was applied on target lepidopteran insects, the compound acts like the steroid hormone 20-hydroxyecdysone by binding onto the ecdysteroid receptor complex of the insect and up or down regulate the expression of a series of genes that controls the molting progress (Hadi et al., 2008). There were insignificant mean percentage of all the three categories namely, clean to light, moderately and severely infested fruit bunches among the three different doses rotated with chlorantraniliprole.

\footnotetext{
The results obtained from different chromafenozide dosage rotated with chlorantraniliprole strongly indicated that by rotating chromafenozide with chlorantraniliprole against oil palm bunch moth, a dose of $500 \mathrm{ml}$ per ha is sufficient to have reasonable control on this particular pest compared to higher dose of $750 \mathrm{ml}$ and 1,000 $\mathrm{ml}$ per ha. This makes chromafenozide a good candidate to be used in rotation with chlorantraniliprole.
}

\section{CONCLUSION}

Based on the results obtained from the optimal dosage of chlorantraniliprole trial, application of $30 \mathrm{~g}$ and $40 \mathrm{~g}$ a.i. per ha chlorantraniliprole outshined the rest and gave the longest control period. Considering the material cost per ha which is one of the most important criteria in pest management decision making, $30 \mathrm{~g}$ a.i. per ha of chlorantraniliprole is recommended as the optimum dosage to be adopted in controlling oil palm bunch moth in oil palm plantation planted on peat. When $30 \mathrm{~g}$ a.i per ha of chlorantraniliprole rotated with $25 \mathrm{~g}$ a.i. per ha chormafenozide in the following experiment with a total of four rounds in a year could yield more than $70 \%$ clean fruit bunches and less than $10 \%$ severely infested fruit bunches from 32 weeks onwards until the end of 52 weeks. With these results, rotation among insecticides with different mode of action seems promising. The recommended chemical rotation regime is $85 \mathrm{~g}$ product per ha of chlorantraniliprole $34.9 \% \mathrm{w} / \mathrm{w}$ used in rotation with $500 \mathrm{ml}$ product per ha of chromafenozide. Further trials are recommended to test out the effectiveness of the combination these insecticides in supressing other pests in the oil palm plantation in order to formulate the most economic and effective oil palm pest management strategy.

\section{ACKNOWLEDGEMENTS}

The authors would like to thank Sarawak Oil Palms Berhad, Miri for support in the field work, and to Universiti Putra Malaysia Bintulu Sarawak Campus for the use of their facilities and technical supports. This research is funded by Grant Putra IPS GPIPS/2017/9541400.

\section{REFERENCES}

Adriana, M. (2003). Environmental fate of indoxacarb. Retrieved March 4, 2021, from https://goforth.com/wpcontent/uploads/2013/10/indoxacarb.pdf.

Ahmed, K.S., El-Bermawy, S.M., Ismael, E.H., AbdelGawwad, R.M. \& Saleh, T.A. (2015). Histopathological effects of diflubenzuron and chromafenozide (IGRs) on egg development in the cotton leafworm Spodoptera littoralis (Boisd.) (Lepidoptera, Noctuidae). Journal of Bioscience and Applied Research, 1(4): 147-153. DOI: 10.21608/jbaar.2015.106020 
Axel, D., Kristin, E.B., Niels, M.F. \& Michael, D.W. (2009). Chlorantraniliprole (Rynaxypyr): A novel DuPont ${ }^{\mathrm{TM}}$ insecticide with low toxicity and low risk for honey bees (Apis mellifera) and bumble bees (Bombas terrestris) providing excellent tools for uses in integrated pest management. In Oomen, P.A. and Thompson, H.M. (eds). Proceedings from $10^{\text {th }}$ International Symposium of the ICP-Bee Protection Group, 8-10 October 2008, Bucharest, Romania. Pp. 548-555.

Becker, N., Zgomba, M., Ludwig, M., Petric, D. \& Rettich, F. (1992). Factors influencing the activity of Bacillus thuringiensis var. israelensis treatments. Journal of the American Mosquito Control Association, 8(3): 285-289.

Brugger, K.E. \& Kannuck, R.M. (1997). Tier 1 environmental risk assessment of DPX-MP062 and competitive insecticides in the USA. Dupont Agricultural Products Document No. AMR 463597.

Chua, C.K., Ooi, K.E., Abdul, R.R., Paula, G.M. \& Lee, K.L. (2010). Chlorantraniliprole: a novel insecticide for bagworm (Metisa plana) control in oil palm plantation. The Planter, 86(1009): 223-235.

Deepak, S., Eitan, B., Robert, M., Ze'ev, B., Sammy, B. \& Arieh, Z. (2001). A UV tolerant mutant of Bacillus thuringiensis subsp. kurstaki producing melanin. Current Microbiology, 44: 25-30. DOI: 10.1007/s00284-001-0069-6

Dunkle, R.L. \& Shasha, B.S. (1989). Response of starchencapsulated Bacillus thuringiensis containing ultraviolet screens to sunlight. Environmental Entomology, 18(6): 1035-1041. DOI: 10.1093/ee/18.6.1035

Ghoneim, K. \& Tanani, M. (2017). Antifeedant activity and detrimental effects of ecdysteroid agonist chromafenozide on the food metabolic parameters of Schistocera gregaria (Forsk.) (Orthoptera: Acrididae). International Journal of Entomology Research, 2(2): 6-16.

Gustavo, M.T., Senseman, S.A., Marchesan, E., Camargo, E.R., Jones, T. \& McCauley, G. (2015). Residues of thiamethoxam and chlorantraniliprole in rice grain. Journal of Agricultural and Food Chemistry, 63(8): 2119-2126. DOI: 10.1021/jf5042504

Hadi, M., Thomas, S., Swevers, L., Kostas, L., Nakagawa, Y. \& Smagghe, G. (2008). Nonsteroidal ecdysteroid agonist chromafenozide: gene induction activity, cell proliferation inhibition and larvicidal activity. Pesticide Biochemistry and Physiology, 92(2): 70-76. 10.1016/j.pestbp.2008.06.004

Lahm, G.P., Selby, T.P., Freudenberger, J.H., Stevenson, T.N., Myers, B.J., Seburyamo, G., Smith, B.K., Flexner, L., Clark, C.E. \& Cordova, D. (2005). Insecticidal anthranilic diamides: a new class of potent ryanodine receptor activators. Bioorganic and Medicinal Chemistry Letters, 15(22): 4898-4906. DOI: 10.1016/j.bmcl.2005.08.034

Lahm, G.P., Stevenson, T.M., Selby, T.P., Freudenberger, J.H., Cordova, D., Flexner, L., Bellin, C.A., Dubas, C.M., Smith, B.K., Hughes, K.A., Hollingshaus, J.G., Clark, C.E. \& Berner, E.A. (2007). Rynaxypyr ${ }^{\mathrm{TM}}$ : a new insecticidal athranilic diamides that acts as a potent and selective ryanodine receptor activator. Bioorganic and Medicinal Chemistry Letters, 17(22): 6274-6279. DOI: 10.1016/j.bmcl.2007.09.012

Mikio, Y., Yoshihisa, T., Tetsuo, W. \& Akiyoshi, K (2006). Development of a novel lepidopteran insect control agent, chromafenozide. Journal of Pesticide Science, 31(2): 163-164. DOI: 10.1584/jpestics.31.182

Parthiban, P., Ravikumar, A. \& Chinniah, C. (2016). Newer insecticidal molecules and their implication on pest management- eco-friendly insecticides for IPM. Advances in Life Sciences. 5(23): 10854-10859. DOI: 10.21894/jopr.2017.2903.04

Saharul, A.M., Zulkefli, M., Ramle, Mohamad, M.R.S., Su, C.M., Siaw, T.C., Norman, K., Siti, R.A.A. \& Siti, N.A. (2017). Biological agents and insecticides to control bunch moth, Tirathaba rufivena in oil palm estates in Sarawak, Malaysia. Journal of Oil Palm Research, 29(3): 323-332. DOI: 10.1603/029.102.0524

Saleh, T.A. \& Abdel-Gawad, R.M. (2018). Electrophoretic and colorimetric pattern of protein and isozyme as reflex to diflubenzuron and chromafenozide treatments of Spodoptera littoralis (Boisd). Journal of Entomology and Zoology Studies, 6(3): 1651-1660.

Saxena, D., Smruti, P. \& Guenther, S. (2010). Fate and effects in soil of cry proteins from Bacillus thuringiensis: influence of physicochemical and biological characteristics of soil. The Open Toxinology Journal, 3(1): 151-171. $10.2174 / 1875414701003010151$

Spomer, A.N., Kamble, S.T. \& Siegfried, D.B. (2009). Bioavailability of chlorantraniliprole and indoxacarb to eastern subterranean termites (Isoptera: Rhinotermitidae) in various soils. Journal of Economic Entomology, 102(5): 1922-1927. DOI: $10.1603 / 029.102 .0524$ 
Su, C.M. (2016). Management of oil palm bunch moth (Tirathaba mundella Walker) in young mature oil palm plantation on peat soil in Sarawak, Malaysia. (Master thesis), Universiti Putra Malaysia, Malaysia.

Su, C.M., King, J.H.P., Kwan, Y.M., Zakry, F.A. \& Ong, K.H. (2020). Economic injury level of oil palm bunch moth, Tirathaba mundella Walker for pest management recommendations in oil palm production. Journal of Oil Palm Research, 33(1): 37-45. DOI: 10.21894/jopr.2020.0090.

Szpyrka, E., Matyaszek, A., \& Slowik-Borowise, M. (2017). Dissipation of chlorantraniliprole, chlorpyrifos-methyl and indoxacarb insecticides used to control codling moth (Cydia pomonella L.) and leafrollers (Tortricidae) in apples for production of baby food. Environmental Science and Pollution Research, 24(13): 12128-12135.
Temple, J.H., Pommireddy, P.L., Cook, D.R., Marcon, P. \& Leonard, B.R. (2009). Susceptibility of selected lepidopteran pests to rynaxypyr, a novel insecticide. The Journal of Cotton Science, 13: 23-31.

Wing, K.D., Sacher, M.E., Kagaya, Y., Tsurubuchi, Y., Mulderig, L., Connair, M. \& Schnee, M. (2000). Bioactivation and mode of action of the oxadiazine indoxacarb in insects. Crop Protection, 19(8-10): 537 545. DOI: 10.1016/S0261-2194(00)00070-3

$\mathrm{Yu}$, S.J. (2014). The toxicology and biochemistry of insecticides. Second Edition. Boca Raton: CRC Press. 